\title{
WHITHER NATIONAL PARKS?
}

\section{(Witir Special Reference to Africa)}

Wild life preservation in Africa and the national park system has as its foundation the 1933 London Convention for the Protection of African Fauna and Flora. Article 2 of this international convention reads : "The expression national park shall denote an area ... set aside for the propagation, protection and preservation of wild animal life and vegetation for the benefit, advantage and enjoyment of the general public ..." and ... "facilities shall, so far as possible, be given to the general public for observing the fauna and flora in national parks."

In the words "so far as possible" can be seen the foreshadowing of an inherent conflict between preservation and public enjoyment. Passage of the years since 1933 has brought this danger nearer. How near the danger to the parks may be, or at least to their survival as true wild life sanctuaries, is shown in the articles from which extracts are reprinted below. In the last of them Colonel Rowland Jones offers noteworthy advice towards the solution of this paradoxical problem.

Tire Impact of Visitors on Game in National Parks

By E. Davison,

\section{Chief Game Warden, Southern Rhodesia National Parks}

(From a paper presented to the 1956 British East and Central Africa Fauna Conference.)

There is no doubt at all that the introduction of visitors to a national park which is essentially a wild life sanctuary, does not constitute a welcome step forward in relation to the fauna of the park, and, as the tourist traffic increases, considerable changes occur in the habits and distribution of the wild life population.

No matter how many regulations are framed to ensure that the visitors to a park do not have a detrimental effect on the animals, it is impossible to enforce these regulations right up to the hilt. Even if staff were available to maintain sufficient patrols to enforce the regulations, the number of staff vehicles on the roads would add to the already heavy flow of traffic; and the staff activities are just as disturbing to the game as are tourists.

Granted there are some animals which will soon accept the flow of traffic and take very little notice of it. Chief of these are elephant bulls, giraffe, wildebeest, zebra, impala and lions, but 
there are others which do not readily accept this state of affairs and are at a disadvantage in the struggle for adequate food and water. These have to select their feeding and drinking areas where they are not disturbed or have to use areas near the tourist roads at night only.

One can visualize a park commercialized to such an extent that all dry season concentration areas and water supplies are so served with roads that only animals which accept the presence of man in motor-cars will survive. Where this is allowed to happen the whole object of a national park will have been defeated.

It is difficult to assess the extent to which tourist traffic can be allowed to interfere with the wild life ecology without doing irreparable damage, and it is hoped that some of the older established parks can produce evidence on which parks in the earlier stages of tourist development can base their calculations for future planning.

In the Wankie National Park the problem is becoming acute, for the popular game concentration areas are naturally the popular tourist rendezvous, and it is becoming noticeable that only a limited proportion of the animals will frequent these areas, if it is at all possible for them to find suitable conditions in an area where they are not disturbed.

\section{Wilat Road tite Kruger Park? \\ By J. C. Shiuts}

(From an article in "Veld and Vlei", November, 1956)

The Kruger Park is no exception to the accepted concept of parks. Its purpose is the preservation for posterity of game in its natural state. Bound up with this, but erroneously defined as its prime object in the Act establishing the park, is that of creating a place where the multitudes of the cities may have an opportunity of sceing and studying wild life.

What has been achieved so far, and what of the future?

The purpose of the old Sabi Game Reserve, now part of the park, as laid down by President Kruger, was to provide a permanent sanctuary for the wild life of this part of the lowveld which was even at that time, fast being wiped out by hunters and natives. The animal was to be the paramount consideration in this park and everything was to be subordinated to its welfare. In this spirit it was administered for many years by Colonel Stevenson Hamilton. His writings and those of Harry Wolhuter describe vividly how most of their efforts were directed 
towards keeping down poaching and teaching the people the then new idea of preservation. There were then no inquisitive hordes of sightseers to disturb the tranquility of the place. The animal was supreme in his pristine surroundings and thriving on it.

But this happy state could not last for ever. Civilization takes its toll, with its restless masses, all thirsting after knowledge and adventure. By 1928 in view of the profusion of animals and pressure from the public, it was thought appropriate to throw the park open to visitors. They did not arrive in a deluge at that stage, for cars were somewhat rudimentary and only a few rough tracks connected the various rest camps. There was no speeding and no dust problem. For some years the park remained in this state, which in many ways represented a happy balance between man and beast. But in time publicity and tourism captured the park and it became an increasingly fashionable holiday resort. More and more cars flocked in and the roads' network grew ever more elaborate. The type of visitor, too, was changing from the true animal lover, who was prepared to rough it, to the luxury addict who put personal comfort first. The emphasis was shifting from spartan camping, to playgrounds for more noisy types out for a good time in the shortest possible period.

The old Park's Board did its best to delay if not to check this trend. They resisted the clamour for cinemas and swimming baths and liquor licences and luxury hotels and all the noisy trappings of the towns. Critics claimed that tourists, especially overseas ones, would not come to the place unless they could do so in comfort. That argument has perhaps been rather overlaboured. But the Park's Boards have become increasingly sensitive to public opinion. The result has been a park getting rapidly cluttered with people, and roads and luxury villages have sprouted up where Skukuza used to shoot his lions. The emphasis has been on luxury and streamline. There was no time to spare a thought for the animals who were mere pawns in a publicity machine.

With expansion goes vast sums of money, and as the park grew it sought ever more greedily after funds. The small amount voted by the Government each year was quite inadequate and the Board has had to devise ways and means of stepping up its own income. This was done partly by raising entrance fees and partly by encouraging more visitors. This latter process involved additional expansion and merely aggravated the vicious circle. The Board has been wise to realize that the point of no return both in regard to finance and general policy was rapidly approaching, and has paused, almost despairingly, to take stock. 
How have the fauna of the park fared in the meanwhile? Having recovered from the ravages of the rinderpest shortly before the Boer War, they prospered well until the early thirties, when a severe drought killed off many beasts. When they recovered from the shock of this disaster they found their home dotted with villages and criss-crossed with a tangle of roads along which cars sped with gay abandon, swamping the bush for miles around with an unpalatable blanket of dust. The animals were foreed to move further afield to cleaner feeding grounds.

It is now agreed by all that game is becoming depleted, is moving off the roads and that distribution of species is undergoing an alarming revision.

Whether it is possible to maintain a park indefinitely is quite another matter, especially one of attenuated shape like the Kruger. Seen in the light that game sanctuaries are artificial and makeshift and that it is impossible to hold back the rhythm of evolution, our efforts undoubtedly appear Canutelike, for all must eventually succumb to inevitable time. We are not masters of the universe and can only delay the inevitable, not forestall it. That is unfortunately, perhaps, quite true, yet while we are endeavouring to practise preservation, at least let us do it well.

If the park is to survive for any length of time we must realize and affirm quite clearly that it is there primarily for the benefit of its fauna. Its visitors and neighbours should only be a secondary consideration and must realize that it is not intended as a super holiday resort.

\section{Nature Conservation and Tourism Planning of National PARKS}

\section{By Colonel Rowland Jones}

(From an article in ", African Wild Life", December, 1956)

The establishment of national parks and game reserves as a medium for wild life conservation is faced initially with three major handicaps : Firstly, the area put aside for conservation has usually not been surveyed biologically, so that the boundaries are man-made and do not conform to nature's requirements; secondly, the local population is antagonistic and wishes to keep the land for farming or other purposes, unless the said land be completely valueless, in which case it is also valueless to game; and thirdly, financial stringency. 
The principles of wild life conservation are, firstly, the preservation of the fauna and flora and secondly, the cultural education of the public. It must be made quite clear that the primary function of conservation concerns the fauna and flora itself and not the people. The latter must be regarded purely as secondary and their wishes must be disregarded completely if and where they conflict with nature's wants, if this is in any way possible.

Let it be assumed that an area has been set aside, the boundaries surveyed and that local prejudice has been overcome. The next step is the appointment of staff to protect and control the reserve. Staff accommodation, roads for communication, machinery for road construction and fire control, and the necessary finances have to be provided by a reluctant government. Until the contemplated reserve is sufficiently established to be exploited, there will be no financial return for the outlay.

At this stage there is little if any noticeable difference in so far as the game in the reserve are concerned, and though the basic material for disturbance may have already been created, there is so little of it that it may well be dismissed, at the very worst, as an essential evil.

After years of skilful and careful management it may be decided that the reserve is sufficiently advaneed to be able to cater for its secondary function-it is ready to be opened to the public. This must be the time when full cognisance must be taken of previous errors and everything necessary for the public must be so planned that the game are affected to the very minimum. The public, on being allowed to tour in the reserve, have two main requirements-roads and sleeping accommodation.

The planning of roads must be considered most carefully. Those required purely for administration and communication should be laid out through areas of the park least frequented by wild life. Tourists on the other hand demand roads from which as much game as possible can be seen. Game have certain seasonal movements. The roads therefore must be so planned that the game is near a road during the season when the reserve is open to the public, but, at the same time, roads must interfere as little as possible with the environment and local movement, particularly at drinking places.

Further, motor traffic must be encouraged not to loiter; a car, which stops, interferes more with the game than a moving vehicle and the layout and construction must be planned to discourage specding.

Visitors will perforce stop where there is game to be seen, and 
during the winter months this will usually occur near waterholes. It is therefore imperative to curtail the length of road from which a waterhole can be seen, otherwise the tendency will be for long lines of stationary cars to form, making an impossible barrier for game wishing to cross over to the waterhole.

The second consideration is accommodation. The original inclination will be to set up small camps in game habitats, possibly a place with large trees overlooking a river, the camp being on the river bank itself. This is most undesirable if the future is to be considered for, if popular, a small camp will develop into a big one and a game habitat will thus be ruined. Accommodation for tourists should be erected in areas not favoured by game and should be regarded only as a place where the night must be spent. Scenic attractions may be included by all means, but, I repeat, avoid putting tourist accommodation in a game habitat.

All this tourist development-from the game point of view this is "spoliation" not "development"-costs money and earns money. Roads and camps are costly to build, entrance fees and camp fees bring in money and the danger of commercialization becomes a real one. The receipts for the first year demonstrate that the reserve is popular and is capable of earning revenue; then if propaganda be wisely sown the receipts will increase yearly. This may well give rise to the fallacy that the reserve is dependent upon its tourist traffic from a monetary point of view. This dangerous half-truth is the pitfall into which even ardent lovers of nature and its conservation will fall, for the evil effects of tourists and traffic on the game are almost imperceptible at first and thus pass unnoticed. Meanwhile demands for more facilities, more comforts, more accommodation and so forth become increasingly insistent until they, themselves, become the primary function and nature conservation may sink into complete oblivion. Commercialization rules the day.

It is a sad thought that nature-loving tourists can have such an ill-effect on nature but to a certain extent the position can be relieved, provided that the position is appreciated by both the administrators of the reserve and the touring public.

It is evident that the public cannot have any conception of the harm done unless they are educated to it by competent, trained officers and are given the lead by the reserve authorities. With the public becoming the "prodigal son" of a reserve, a certain amount of pandering to their wishes takes place and exaggerated importance is attached to their financial value. 
The effect of tourism on game itself can be divided into two sections ; firstly, the interference caused by work done in a reserve such as road and camp construction, water and petrol supplies and all the attendant services, and, secondly, the interference to game caused by the tourist himself.

The first should be so obvious that it needs little elaboration, the thunder of road machinery, heavy lorries, perpetual noise and the like cannot cause tranquillity, and the disturbing effect is very obvious once the matter has been considered.

The effect of tourist cars and the behaviour of the occupants is not so evident whilst the traffic density remains low but where this increases the results can be seen by comparison with previous conditions. The effect of this traffic varies on each species of game, but however great or little this effect may be it cannot but be harmful. Impala for instance become so tame that they are practically born amongst the cars and live and die amongst them. This excessive tameness is not natural and will further upset the balance due to the fact that other species in the same habitat may move out, and the impala by reason of their tameness, take over the area.

Waterbuck on the other hand do not like traffic and will give a wide berth to roads. This may mean that they are denied their natural water or grazing until traffic ceases. Under these conditions it is clear that breeding and so forth will be affected.

This is, in effect, what actually happens, though there are of course other factors which affect game such as carnivora, poaching, veld fires, water supplies, etc., but the scope of this article deals with the tourism aspect only. With the knowledge now at our disposal the future planning of reserves or national parks should cause little difficulty. Provided that the primary functions are always kept in the forefront, the harm done by spoliation can be maintained at the lowest level. 